\title{
Analysis of global three-dimensional aerosol structure with spectral radiance matching
}

\author{
Dong Liu ${ }^{1}$, Sijie Chen ${ }^{1}$, Chonghui Cheng ${ }^{1}$, Howard W. Barker ${ }^{2}$, Changzhe Dong ${ }^{3}$, Ju Ke $^{1}$, Shuaibo Wang ${ }^{1}$, and \\ Zhuofan Zheng ${ }^{1}$ \\ ${ }^{1}$ State Key Laboratory of Modern Optical Instrumentation, College of Optical Science and Engineering, Zhejiang \\ University, Hangzhou, Zhejiang, 310027, China \\ ${ }^{2}$ Environment and Climate Change Canada, Toronto, ON, Canada \\ ${ }^{3}$ Shanghai Institute of Satellite Engineering, Shanghai, 201109, China
}

Correspondence: Dong Liu (liudongopt@zju.edu.cn)

Received: 6 May 2019 - Discussion started: 25 June 2019

Revised: 30 October 2019 - Accepted: 4 November 2019 - Published: 11 December 2019

\begin{abstract}
A method is assessed which expands aerosol vertical profiles inferred from nadir-pointing lidars to crosstrack locations next to nadir columns. This is achieved via matching of passive radiances at off-nadir locations with their counterparts that are collocated with lidar data. This spectral radiance matching (SRM) method is tested using profiles inferred from Cloud-Aerosol Lidar and Infrared Pathfinder Satellite Observation (CALIPSO) lidar observations and collocated Moderate Resolution Imaging Spectroradiometer (MODIS) passive imagery for the periods 10-25 April and 14-29 September 2015. CALIPSO profiles are expanded out to $100 \mathrm{~km}$ on both sides of the daytime ground track. Reliability of constructed profiles that are removed from the ground track by number of kilometers are tested by requiring the algorithm to reconstruct profiles using only profiles that are removed from it along track by more than the number of kilometers. When sufficient numbers of pixels and columns are available, the SRM method can correctly match $\sim 75 \%$ and $\sim 68 \%$ of aerosol vertical structure at distances of 30 and $100 \mathrm{~km}$ from the ground track, respectively. The construction algorithm is applied to the eastern coast of Asia during spring 2015. Vertical distributions of different aerosol subtypes indicate that the region was dominated by dust and polluted dust transported from the continent. It is shown that atmospheric profiles and aerosol optical depth (AOD) inferred from ground-based measurements agree with those constructed by the SRM method. For profiles, the relative errors between those measured by ground-based lidar and those constructed in the surrounding
\end{abstract}

area are similar to the relative errors between the groundbased station and CALIPSO overpass at the closest distance. For AOD, the measurements from the ground-based network agree with those inferred from constructed aerosol structure better than direct observations from CALIPSO and close to those inferred from MODIS radiances.

\section{Introduction}

Aerosol vertical structure (AVS) plays an important role in Earth's climate system. Aerosols affect changes in radiative fluxes by scattering and absorbing solar radiation as well as modifying cloud physical properties (IPCC, 2013). Studies of Saharan dust transport (Guerrero-Rascado et al., 2008) and Pacific air-pollutant transport (Xu et al., 2019) indicate that AVS is a key parameter needed to evaluate the production, transport, and removal of aerosols. Considering the effect of external and internal mixing of aerosols during this process, understanding AVS also helps improve descriptions of optical properties of aerosols. Similarly, the presence of aerosols induces diverse cloud responses by acting as condensation and ice nuclei (Breon et al., 2002; Textor et al., 2006). Therefore, detailed information of AVS is necessary to understand the vertical structure of clouds and precipitation (Guo et al., 2018). 
The current understanding of AVS is limited by the amount of observations made across the globe. Traditional techniques rely on airborne campaigns to collect aerosols using filters on in situ instruments (Moosmuller et al., 2009). Recently, however, the amount of relevant information has been boosted by the advent of satellite-based remote sensing. The passive sensor Moderate Resolution Imaging Spectroradiometer (MODIS), aboard the Terra and Aqua satellites since 1999 and 2003, respectively, has provided global measurements almost daily (Platnick et al., 2003; Levy et al., 2013). MODIS data are used routinely to infer aerosol optical depth (AOD). Such inferences, however, lack information pertaining to AVS. The inability to separate aerosol layers leads to difficulties in interpreting aerosol transport, as high near-surface concentrations can overpower thinner layers transported aloft. In addition, MODIS is not well-suited for distinguishing aerosol type, thereby making it difficult to study aerosol variations in time, space, and combinations of emission sources.

The development of lidar technology helped provide these vital missing pieces of information. Ground-based lidar systems have been stationed at various locations and also used in field campaigns to measure the vertical and horizontal distribution of aerosols (Welton et al., 2000, 2002; Badarinath et al., 2010). Ground-based lidars provide measurements for the fixed locations with a timescale of minutes to hours, depending on the specific type of lidar used in the experiment. Limited by the stationary setting, ground-based lidars could not achieve true global coverage; nevertheless, networks of ground-based lidars (e.g., Micro-Pulse Lidar Network - MPL-NET, European Aerosol Research Lidar Network - EARLINET, and Asian dust and aerosol lidar observation network - AD-NET) provide key insights into atmospheric study and are involved in validation of satellite sensors (Kovacs et al., 2004; Mamouri et al., 2009; Pappalardo et al., 2010).

The Cloud-Aerosol Lidar and Infrared Pathfinder Satellite Observation (CALIPSO) satellite, launched in 2006, provides greater insight into AVS (Winker et al., 2009). CALIPSO's active sensor, the Cloud-Aerosol Lidar with Orthogonal Polarization (CALIOP), has the ability to resolve vertical structures of optically thin clouds and aerosols at the global scale. Yet, with its narrow nadir-viewing geometry, CALIPSO repeatedly samples only $0.2 \%$ of the Earth every $16 \mathrm{~d}$ (Kahn et al., 2008). This low frequency and small coverage makes it difficult to study regional AVS with CALIPSO products.

Collocation of passive and active sensors can, however, provide synergistic insights. The A-Train constellation, which includes Aqua and CALIPSO, has made many breakthroughs. Satellites of the A-Train constellation are in a $705 \mathrm{~km}$ sun-synchronous polar orbit, with an Equator crossing time of about 13:30 local solar time, and are in close proximity to one another. The success of the A-Train has led to plans to launch other active-passive satellites, such as the
Earth Cloud Aerosol and Radiation Explorer (EarthCARE) mission (Illingworth et al., 2015). China has its own plan to launch a multifunctional observation satellite equipped with a high-spectral-resolution lidar (HSRL), a Mie lidar, and a wide-swath cloud and aerosol imaging spectrometer targeting, among other things, AVS. Recognizing the limitations of using either passive sensors or active instruments, ideas for combining active-passive observations, both ground-based and space-borne, have been advanced and tested (Barker et al., 2011; Miller et al., 2014; Forsythe et al., 2000; Hutchison et al., 2006; Sun et al., 2016).

In the current study, global three-dimensional (3-D) distributions of AVS are constructed utilizing CALIPSO and MODIS (Aqua) observations. 3-D aerosol structure is constructed by selecting and substituting potential donors (pixels from CALIPSO profiles) for off-nadir recipient pixels within the MODIS swath based on the similarity of their multispectral radiances. It is proposed that expansion of CALIPSO's aerosol vertical profile into the cross-track direction can fill gaps between CALIPSO tracks, thereby allowing real global estimation of AVS. In addition, the construction provides reliable estimates of nearby AVS simultaneously with lidar measurements. The information of regional AVS has the potential to help understand short-term aerosol events, such as the heavy haze events that frequently occur in northeastern China (Zhang et al., 2015). It could also provide assessment of cloud-aerosol interaction over a broader range than the lidar ground track (Chand et al., 2008).

Construction of AVS follows the method of scene construction proposed by Barker et al. (2011) for the EarthCARE mission. In essence, if a donor and a recipient pixel have sufficiently similar radiances, their vertical structures and column properties of clouds and aerosols are also assumed to be similar, implying that the donor's properties can be assigned to the recipient. This method, referred to here as spectral radiance matching (SRM), has been tested with respect to clouds. Barker et al. (2011) constructed 3$\mathrm{D}$ distributions of clouds and computed broadband radiative fluxes using 1-D and 3-D radiative transfer models. Results for $\sim 100 \mathrm{~km}^{2}$ domains showed good consistency when compared to measurements from Clouds and the Earth's Radiant Energy System (CERES; Loeb et al., 2005, 2007). The quality of active-passive retrievals was further analyzed by Barker et al. (2014).

The objective of this study is to construct and analyze global 3-D AVS with two $16 \mathrm{~d}$ repeat cycles of A-Train data from 10-25 April and 14-29 September 2015. AVS distributions from two seasons are compared to MODIS and CALIPSO quantities. This gives an indication of how use of MODIS-only or CALIPSO-only data might be affected by gaps in observations. To test the reliability of the constructed AVS, profiles along track are reconstructed based on the same algorithm used for construction. The matching rate (MR) between reconstructed and measured profiles pro- 
vides an approximation of the success of SRM method for aerosols.

This paper is organized as follows. Section 2 provides a brief background on the datasets used here. Section 3 reviews the SRM method, including construction and reconstruction algorithms. Section 4 assesses global construction results for two $16 \mathrm{~d}$ repeat cycles. The last subsection presents a case study of 3-month observations along the eastern coast of Asia. AOD and occurrence frequency of aerosol subtypes are analyzed. Section 5 provides a summary as well as commentary on limitations of the scene construction algorithm for aerosols and scope for future applications.

\section{Data}

The SRM method for atmosphere scene construction is based on cloud and aerosol properties synergistically retrieved from active and passive sensors. In this study, we use data from CALIPSO and Aqua satellites, which make observations close in space and time (Savtchenko et al., 2008). Before CALIPSO exited the A-Train on 13 September 2018, it was flying about $73 \mathrm{~s}$ behind Aqua with its MODIS. Due to sunglint, CALIPSO was positioned $215 \mathrm{~km}$ to the antisolar side of Aqua's ground track at the ascending node (vice versa on the descending node), but the wide swaths of MODIS guarantee constant collocation. Hereinafter, unless stated otherwise, "ground track" refers to CALIPSO's ground track.

\subsection{CALIPSO product and MODIS product}

CALIPSO carries the three-channel elastic backscattering CALIOP with passive infrared and visible imagers (Winker et al., 2002). CALIOP observes the vertical and horizontal distribution of cloud and aerosol layers, which are reported in the Level 2 vertical feature mask (VFM) product (Vaughan et al., 2009). VFM products are recorded in nominal increments of 15 consecutive laser pulses, which is equivalent to a distance of $5 \mathrm{~km}$ along track. Vertical resolution of the VFM product varies from 30 to $300 \mathrm{~m}$ (Hunt et al., 2009; Winker et al., 2010), and it is stored as a sequence of feature classification flags with 5515 element arrays (i.e., as an $N \times 5515$ matrix, where $N$ is the number of pixels recorded in the file). Each array is identified with the following: clear air (1), cloud (2), tropospheric (Aerosol(tro)) aerosol (3), stratospheric (Aerosol(str)) aerosol (4), surface (5), subsurface (6), no signal (7), or invalid (0 stands for bad or missing data). In this study, the VFM product was treated as the "true" indicator of atmosphere structure. This means that uncertainties in the product propagate to analyses of results derived from it. To minimize this impact, only arrays identified with high confidence - with cloud-aerosol discrimination (CAD) scores larger than 70 - were used. In addition, attention was paid to extinction quality assurance (QA) flags. For most constructed scenes, only aerosols layers with a QA flag of 0 and 1 were included. This helped avoid large errors that can stem from the nonlinear behavior of the AOD retrieval (Huang et al., 2015a). CALIPSO products used in the work are from Version 4.20.

The MODIS passive sensor has 36 channels, spanning visible to thermal wavelengths. MODIS Level 1 products contain calibrated radiances at the $1 \mathrm{~km}$ resolution (MYD021KM) and are used to infer several key properties of clouds and aerosols (Kaufman et al., 2002; Minnis et al., 2008; Levy et al., 2013; Platnick et al., 2017). Pixel locations and ancillary information (MYD03) are used by the algorithm discussed in the next section. Because MODIS retrieval errors increase with solar and viewing zenith angles (Kato and Marshak, 2009), analyses were restricted to between $60^{\circ} \mathrm{N}$ and $60^{\circ} \mathrm{S}$. MODIS products used in the work are from MODIS Collection 6.

The MODIS wide swath $(2330 \mathrm{~km}$ cross track) ensures collocated observations with CALIPSO. Their narrow collocation track is referred to as the active-passive retrieved cross section (RXS; see Barker et al. 2011). In the following sections, the actual RXS is referred as "RXS-nadir", while the RXS as expanded by the SRM method, up to $100 \mathrm{~km}$ on both sides of the RXS-nadir, is referred to as "RXS-expand".

As CALIPSO products are provided at $5 \mathrm{~km}$ resolution, and MODIS products at $1 \mathrm{~km}$, they were merged using a grid formed by the latitude and longitude of the first and the last laser shot, with the cross-track width doubled to ensure that the grid is larger than $1 \mathrm{~km}$. Radiances, the solar zenith angle, and the solar azimuth angle geolocated within each grid were averaged. In terms of surface type, if one grid contained both the land and sea flag from MODIS, it was redefined as a mixed surface type. The same grid size was applied to RXSexpand.

\section{Method}

\subsection{Spectral radiance matching (SRM) method}

Barker et al. (2011) proposed a scene construction algorithm to extend cloud-aerosol profiles in the RXS-nadir to nearby off-nadir positions. They also provided a reconstruction algorithm to assess the construction algorithm's performance. The construction algorithm is based on matching spectral radiances of nadir pixels with those of off-nadir pixels, while the reconstruction algorithm mimics the process by setting a dead zone around RXS pixels and filling them with other RXS pixels that reside outside of the dead zone. The method is reiterated briefly here for the convenience of readers.

To match and substitute the most suitable donor at location $(m, 0)$ on the RXS for each off-nadir recipient at location $(i, j)$ in the passive swath $j \in[-J,-1] \cup[1, J]$, the SRM method computes a cost function $F(i, j ; m)$ during daytime 
as

$$
\begin{gathered}
F(i, j ; m)=\sum_{k=1}^{K=4}\left(\frac{r_{k}(i, j)-r_{k}(m, 0)}{r_{k}(i, j)}\right)^{2}, \\
m \in\left[i-m_{1}, i+m_{2}\right],
\end{gathered}
$$

where $r_{k}$ is MODIS radiance for the $k$ th band, and $m \in[i-$ $\left.m_{1} \cup i+m_{2}\right]$ is the range of potential donors along the RXS. Potential donors also need to satisfy the following: (1) having the same underlying surface type as the recipient, (2) having similar solar zenith and solar azimuth angles as at the recipient, (3) having a CAD score where $|C A D| \geq 70$. See Barker et al. (2011) for details explaining each condition. For this study, $K=4$ was used (0.62-0.67, 2.105-2.155, 8.4-8.7, and $11.77-12.27 \mu \mathrm{m})$. The bands are chosen for their widely accepted usage in retrieving cloud properties, including cloud cover, cloud top properties (cloud top pressure - CTP; cloud top temperature - CTT; and cloud top height - CTH), and cloud phase (Ackerman et al., 1998; Baum et al., 2012, 2000) as well as aerosol properties (Sayer et al., 2014; Levy et al., 2013; Remer et al., 2013). The possible combinations of different bands have been tested, and details are provided in Sect. 3.2.

To ensure the number of potential donors for far off-nadir recipients, search range was adopted from Sun et al. (2016) and defined as

$m_{1}=m_{2}=\left\{\begin{array}{l}200 ; \ldots D_{m} \leq 30, \\ 200+D_{m} ; \ldots D_{m}>30,\end{array}\right.$

where $D_{m}$ is the shortest distance between recipient and RXS. $F(i, j ; m)$ is then ordered from smallest to largest, and the Euclidean distance between a potential donor at $(m, 0)$ and the recipient at $(i, j)$ is calculated as

$D(i, j ; m)=\Delta L \sqrt{(i-m)^{2}+j^{2}}$,

where $\Delta L$ is horizontal resolution $(1 \mathrm{~km})$ of MODIS radiance measurements. The most suitable donor is found by solving

$$
\underset{m^{*} \in\left[1,\left(m_{1}+m_{2}+1\right) f\right]}{\arg \min }\left\{D\left(i, j ; m^{*}\right)\right\} ; f \in(0,1),
$$

which means that the selected donor, noted with an asterisk $\left(m^{*}, 0\right)$, is closest to the recipient and has sufficiently similar radiances. $f=0.15$ was used here rather than 0.03 as in Barker et al. (2011). This is because CALIPSO aerosol products have a lower resolution $(5 \mathrm{~km})$ than cloud products (1 km).

The reconstruction algorithm, on the other hand, is designed to evaluate the performance of the construction algorithm, since the reconstructed results along the RXS can be compared to the actual observations. A dead zone centered at the recipient $(i, 0)$ is set by defining the selection range for potential donors as $\left[i-m_{1}, i-n\right] \cup\left[i+n, i+m_{2}\right]$. By barring selections of potential donors from the nearest $\pm n$ pixels, the reconstruction process is forced to resemble the filling of an off-nadir recipient removed from the RXS by $n$ pixels. The results of reconstruction thus give an approximate indication of how well the SRM method can be expected to perform.

\subsection{Selection of bands for aerosol applications}

Since the construction algorithm is initially developed for clouds, efforts have been made to apply the algorithm to aerosols. The following test is performed to find the possible combination of bands most sensitive to aerosols; $30 \mathrm{~d}$ of CALIPSO profiles on the eastern coast of China in 2015 are selected and screened with clear-sky and heavy aerosol loading conditions. The manually selected cloudless datasets with heavy loading events are expected to give a clear indication of whether the algorithm could work for aerosols or not. The following combinations of radiance bands are tested: (1) a combination of bands 1, 7, 29, and 32 used by Barker et al. (2011); (2) a combination of bands 1 and 7 only; and (3) a combination of visible bands $1,2,3$, and 4 . The performance of the algorithm using these combinations is evaluated by reconstructing the profile with the dead-zone setting for 30 and $100 \mathrm{~km}$.

A typical comparison among the reconstructed profiles is shown in the Fig. 1, where Fig. 1a is the original profile, Fig. 1b-d correspond to combination 1 to 3 described above, and Fig. 1e shows the reconstructed profile from directly choosing the closest pixels outside of the dead zone. The results of the test indicate that the bands used by Barker et al. (2011) could obtain a pretty successful reconstruction. The matching rates at 30 and $100 \mathrm{~km}$ are on average $81.9 \%$ and $75.2 \%$, respectively, which means that this combination can be used to construct aerosol vertical structure. In contrast, using visible bands only has a lower matching rate (around 60\%-70\%), especially when aerosol layers aloft are present. Selecting the closest pixel, on the other hand, has a very high matching rate at $30 \mathrm{~km}$, which is expected, since aerosol properties are relatively horizontally uniform. However, as the dead-zone range increases or in cases in which aerosol layer is not continuous, the simple horizontal shift leads to more errors. Based on the test results with heavy aerosol loading events, the combination of bands for aerosol application is the same as the wavelength selection in Barker et al. (2011).

\subsection{Theoretical best matching (TBM) method}

Differences between reconstructed profiles and CALIPSO observations can have two main causes: (1) the SRM method does not select the best matching donor from the potential donors, and (2) the profiles for the actual best matching donor and the recipient differ. To analyze the contribution of these two causes, a theoretical best matching (TBM) method was devised to purposely select the most suitable donor from the 


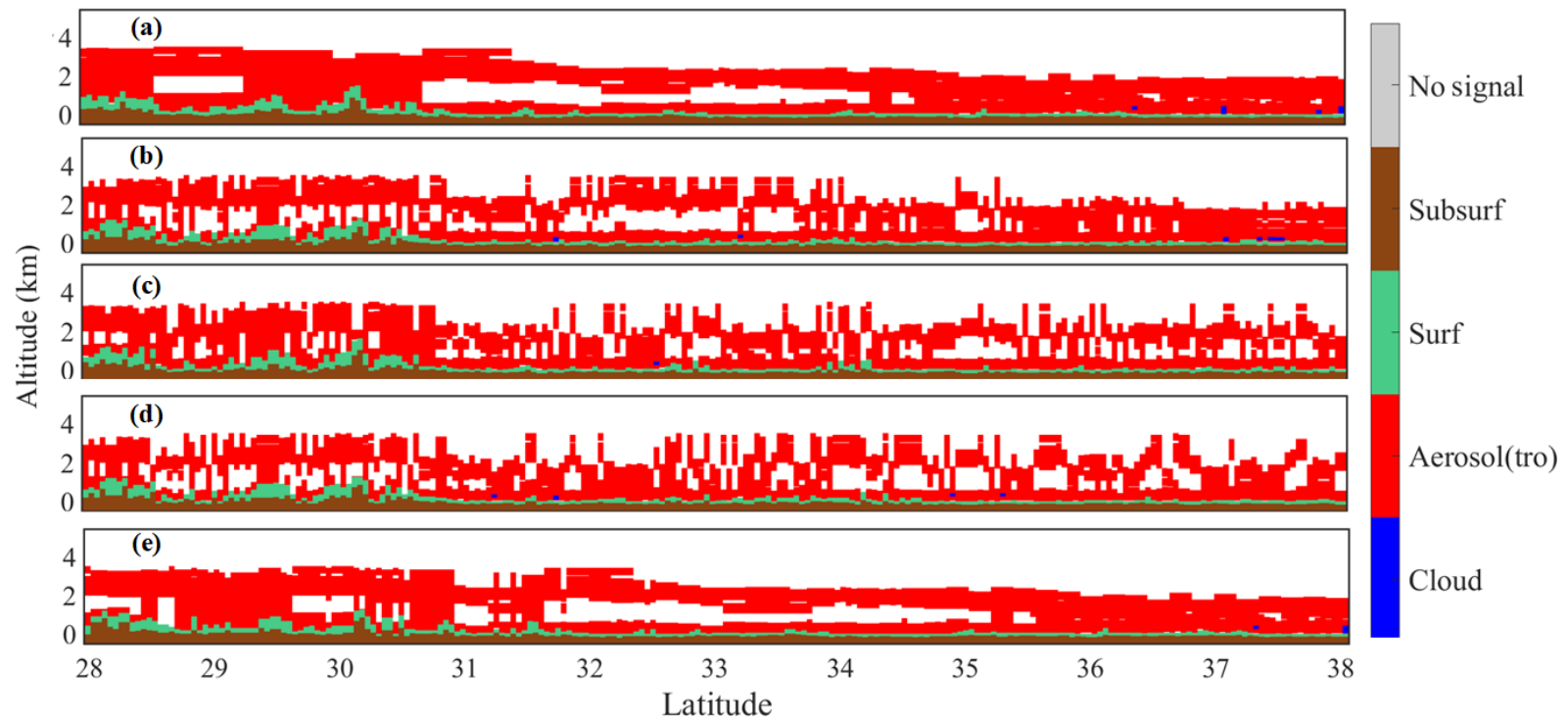

Figure 1. Reconstruction of CALIPSO profile passing the eastern coast of China on 3 January 2015 with dead-zone setting for $100 \mathrm{~km}$. The panels show the original profile and reconstructed profiles using different combinations of radiance bands.

Table 1. Contingency tables for the comparison of the reconstructed profile using SRM method to CALIPSO VFM product.

\begin{tabular}{|c|c|c|c|c|c|}
\hline Agree & Recipient & Donor & Disagree & Recipient & Donor \\
\hline \multirow[t]{2}{*}{ Agree $_{\mathrm{cr}}$} & 1 & 1 & Disagree $_{\text {cr-cd }}$ & 1 & 2 \\
\hline & & & Disagree $_{c r-a e}$ & 1 & 3 or 4 \\
\hline \multirow[t]{2}{*}{ Agree $_{c d}$} & 2 & 2 & Disagree $_{\mathrm{cd}-\mathrm{cr}}$ & 2 & 1 \\
\hline & & & Disagree $_{c d-a e}$ & 2 & 3 or 4 \\
\hline Agree $_{\mathrm{ae}}$ & 3 & 3 & Disagree $_{\mathrm{ae}-\mathrm{cr}}$ & 3 or 4 & 1 \\
\hline \multirow[t]{3}{*}{ Agree $_{\mathrm{ae}}$} & 4 & 4 & Disagree $_{a r-c d}$ & 3 or 4 & 2 \\
\hline & & & Disagree $_{\text {suf }}$ & $1-4$ & 5 or 6 \\
\hline & & & Disagree $_{\text {nosig }}$ & $1-4$ & 7 \\
\hline
\end{tabular}

The arrays are interpreted as clear air (1), cloud (2), tropospheric aerosol (3), stratospheric aerosol (4), surface (5), subsurface (6), or no signal (7).

potentials. In theory, the result from the TBM method is the best that can be expected from the SRM method as defined. If for every column along the ground track, an identical column exists within range but outside of the dead zone, the TBM method would reconstruct the original profiles perfectly. Therefore, differences between the TBM method's reconstructed profiles and original profiles indicate the influence of the second cause. Differences between reconstructed profiles from the TBM method and constructed profiles from the SRM method, on the other hand, indicate the influence of the first cause.

The TBM method of reconstruction is calculated by comparing CALIPSO's VFM for each potential donor (constrained by dead zone) to that of the recipient. The comparison between reconstructed results and a VFM is categorized as shown in Table 1. Results of each array are classified as results that "agree" or "disagree" for clear (1), cloud (2), or aerosol ( $3=$ tropospheric; $4=$ stratospheric). Recipient arrays that are identified with the categories of "no signal" are (7) and "invalid" (0) and are not counted when comparing with possible donors as the actual scenes at these elements are unknown. Recipient arrays that are identified as surface (5) or subsurface (6) are also not counted, as matches of these two feature types are considered less important. On the other hand, arrays classified under the categories of no signal, invalid, surface, or subsurface for potential donors are counted as those that "disagree" when compared to the recipient. Hence, a matching rate can be calculated as

$\mathrm{MR}=\left(\right.$ Agree $_{\mathrm{cr}}+$ Agree $_{\mathrm{cd}}+$ Agree $\left._{\mathrm{ae}}\right) / N$,

where $N$ is the total number of VFM arrays measured along the ground track that are identified as clear air, clouds, or aerosols. The potential donor with the largest MR is selected as the donor for the TBM method.

\section{Results and discussion}

Results are presented in three subsections. The first two diagnose the construction algorithm, while the third employs it specifically to the eastern coast of Asia.

\subsection{Expansion of active-passive retrieved cross section (RXS)}

This section presents results of constructed and reconstructed aerosol properties using two full CALIPSO $16 \mathrm{~d}$ repeat cycles in 2015 and a comparison of the TBM results against original observations. From 10-24 April and 14-29 Septem- 
ber, CALIPSO functioned normally except during a boresight diagnostic and alignment on 18 September, losing about half of that day's data. Because MODIS retrievals of aerosol properties depend mainly on visible wavelengths, only daytime observations were used in this study.

Table 2 summarizes frequencies of occurrences of atmosphere conditions. These numbers refer to the occurrence of atmospheric features as the percentage they occupied in the vertical column. We calculated this occurrence rate according to CALIPSO VFM products, which was then scaled for the vertical and horizontal resolution of the products (Hunt et al., 2009). The majority of conditions were identified as clear. Above $8.2 \mathrm{~km}$ clear arrays occur over $90 \%$ of the time. Aerosols and clouds occurred below $8.2 \mathrm{~km}$ in about $7 \%$ and $5 \%$ of the cells, respectively. Note that arrays that identified as no signal represent $16 \%-18 \%$ of cells in this layer; CALIPSO's signal can be totally attenuated beneath opaque clouds and certain aerosols. This indicates that the numbers in Table 2 likely underestimated the amount of clouds and aerosols in the actual atmosphere. After removing elements identified as no signal, surface, and subsurface, aerosols and clouds occupied $4.43 \%-4.52 \%$ and $5.35 \%-6.15 \%$ of the cells; clear skies account for the remainder. The horizontal cloud coverage between $60^{\circ} \mathrm{N}$ and $60^{\circ} \mathrm{S}$ for the tested periods in April and September 2015 is $68.7 \%$ and $71.3 \%$, respectively.

The RXS is expanded to $100 \mathrm{~km}$ on both sides of it by constructing profiles along 40 parallel tracks every $5 \mathrm{~km}$. Figure 2 shows an example of a CALIPSO track passing the African coast on 23 April 2015 between $5^{\circ} \mathrm{S}$ and $15^{\circ} \mathrm{N}$. For better visualization, only four extended tracks are shown on both sides of the CALIPSO track, each separated by $25 \mathrm{~km}$. The clear arrays on the extended tracks are made transparent.

Height-resolved global AOD maps (averaged for a $2^{\circ} \times 2^{\circ}$ latitude-longitude grid) based on the two selected periods are shown in Fig. 3. In the near-surface layer, at $2 \mathrm{~km}$ a.g.l. (above ground level), in April, relatively high aerosol loadings are found in the cross-Atlantic African dust transport, Saudi Arabia, and India. In September, dust dynamics are much weaker, but much biomass burning is apparent in the Brazilian Amazon and southern Africa. This seasonal trend of dust and smoke is more obvious in the layer $2-4 \mathrm{~km}$ a.g.l. Aerosol aloft in this layer is expected to be undergoing longrange transport. In April, the thickest dust layers are found slightly inland of the western coast of Africa, at around $12.5^{\circ} \mathrm{N}, 5.5^{\circ} \mathrm{E}$, and in the center of Saudi Arabia, at around $24.5^{\circ} \mathrm{N}, 42.5^{\circ} \mathrm{E}$. The shift of AOD distribution between the surface layer and layer above is logical and indicates the movement of dust layers as the aerosol loadings are transported towards the oceans. In September, this contrast is harder to observe, as the dust dynamic is weaker, but similar trends are found in the biomass-burning regions. In addition, persistent high aerosol loadings in both $0-2$ and 2$4 \mathrm{~km}$ a.g.l. are found in India and on the eastern coast of China with mixed sources of natural aerosols and pollutants.
The results could be affected by the local topography. Marine aerosols are confined largely to the near-surface layer, with some vertical transport in southeastern Asia in September due to the Asian monsoon. The observed pattern is mostly consistent with other studies in terms of global distribution and seasonal variations (Martins et al., 2018; Liu et al., 2012; Chen et al., 2018). In comparison, globally averaged AOD from RXS-expand is 0.0027 larger than observations made by CALIPSO in April and 0.0028 larger in September. Both positive and negative differences exist in regions with high aerosol loadings, but none of the regions exhibit consistent high or low biases. Therefore, these insignificant differences are likely caused by random errors in the algorithm in conjunction with CALIPSO's unbiased sampling and suggest that aerosol distributions constructed using SRM method do not change the global aerosol mass as inferred directly from CALIPSO data.

\subsection{Reconstruction of RXS-nadir}

To evaluate the reliability of its result, RXS cross sections were reconstructed for dead zones set to 30 and $100 \mathrm{~km}$, which should give an approximate evaluation of the chances of successfully constructing scenes nearby and are well removed from the RXS. Detailed analysis of the matching rate between reconstructed RXS and RXS-nadir is summarized in Table 3.

During each $16 \mathrm{~d}$ cycle, there were about 600000 CALIPSO observations made in the selection range. With the dead zone set to $30 \mathrm{~km}$, about $95 \%$ of them, as recipients, are matched up with selected donors. The remaining $5 \%$ are not matched because no suitable donors are found in the range of conditions described in Sect. 3. This ratio increases with the distance of dead zone because the number of potential donors that meet the requirement of surface type and solar angles decreases with increasing distance between the donor and recipient. When dead zone is set to $100 \mathrm{~km}$, only about $71 \%$ of recipients are matched with a donor. The following analysis focuses on the portion of recipients matched up with donors, unless mentioned otherwise.

Overall, at $30 \mathrm{~km}$, the reconstruction based on the SRM method correctly matches $92.04 \%$ of air columns in April and $92.55 \%$ in September. At $100 \mathrm{~km}$, the SRM method correctly matches $88.57 \%$ of air columns in April and $89.68 \%$ in September. To investigate the reasons behind imperfect reconstruction, the correctly reconstructed arrays and incorrectly reconstructed arrays are analyzed separately (see Table 3).

The same analysis is also performed with the TBM reconstruction in which $96.87 \%$ of the air column is correctly reconstructed in April and $92.55 \%$ in September at $30 \mathrm{~km}$. At $100 \mathrm{~km}, 93.95 \%$ of the air column is correctly reconstructed in April and $94.76 \%$ in September. As discussed in Sect. 3.2, the difference between TBM reconstruction and perfect reconstruction (i.e. $100 \%$ correct reconstruction of nadir pro- 
Table 2. Summary of atmosphere condition from 10 to 24 April and from 14 to 29 September 2015.

\begin{tabular}{lrrrrrr}
\hline & Aerosol(str) & Aerosol(tro) & Clear & Cloud & No signal & Surf or subsurf \\
\hline $20.2-30.1 \mathrm{~km}$ & $0.14 \%$ & - & $99.84 \%-99.85 \%$ & $0.01 \%-0.02 \%$ & - & - \\
$8.2-20.2 \mathrm{~km}$ & $0.038 \%$ & $0.24 \%-0.28 \%$ & $91.87 \%-93.71 \%$ & $4.77 \%-6.41 \%$ & $1.24 \%-1.31 \%$ & - \\
$-0.5-8.2 \mathrm{~km}$ & - & $7.08 \%-7.12 \%$ & $63.42 \%-65.32 \%$ & $5.48 \%-5.68 \%$ & $16.48 \%-18.13 \%$ & $5.64 \%$ \\
\hline
\end{tabular}

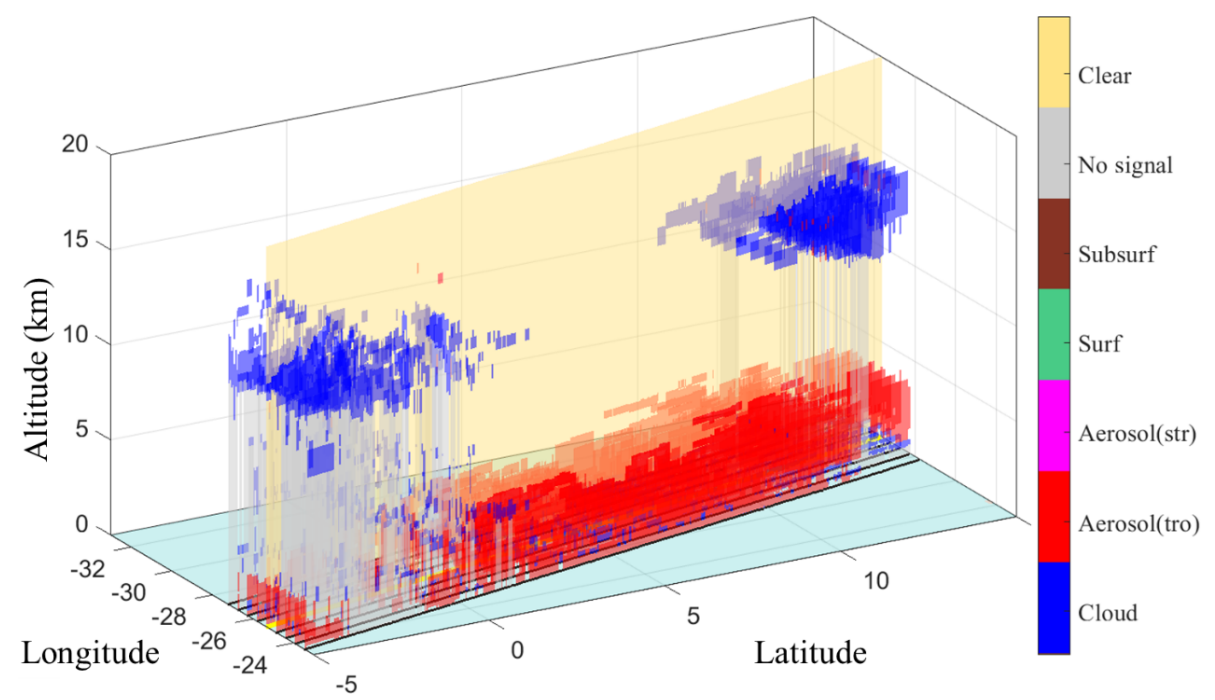

Figure 2. Demonstration of the expansion of the active-passive retrieved cross section (RXS), which runs through the center, for a transect near African Atlantic coast between $15^{\circ} \mathrm{N}$ and $5^{\circ} \mathrm{S}$ on 23 April 2015.

files) indicates the errors caused by selection from limited numbers of donors.

On the other hand, differences between TBM reconstruction and SRM reconstruction indicate that the SRM method still needs improvement. In comparison, over $50 \%$ of the mismatches by TBM reconstruction come from clear arrays, which is higher than that from SRM reconstruction. The fraction of no signal (5\%-9\%) in the mismatch of the TBM reconstruction is much lower than that of SRM reconstruction. This results partly from the procedure of the TBM method, which tends to choose donors with less arrays of no signal. The fractions of mismatch of clouds and aerosols are not significantly different between the methods.

Since the analysis of the entire air column is easily overwhelmed by clear arrays, the matching rate with respect to aerosols is calculated. The ratio is obtained as the number of correctly reconstructed aerosol arrays divided by the total number of aerosol arrays in the original profile (both correctly and incorrectly matched in the reconstructed profile), and other arrays mismatch as aerosols in the reconstructed profile.

The average matching rate with respect to aerosols across the globe is $68.18 \%$ at $30 \mathrm{~km}$ and $62.33 \%$ at $100 \mathrm{~km}$. The matching rate is higher over land than over ocean, possibly because there are more aerosols over land. The matching rate also shows a general trend with latitude. At $30 \mathrm{~km}$, the aver- age matching rate is $73.78 \%$ between 14 and $24^{\circ} \mathrm{N}, 71.79 \%$ between 14 and $24^{\circ} \mathrm{S}$, and $66.92 \%$ between 4 and $4^{\circ} \mathrm{S}$. At $100 \mathrm{~km}$, the average matching rate is $67.43 \%$ between 14 and $24^{\circ} \mathrm{N}, 66.18 \%$ between 14 and $24^{\circ} \mathrm{S}$, and $59.91 \%$ between $4^{\circ} \mathrm{N}$ and $4^{\circ} \mathrm{S}$. This is linked to the persistent high cloud fraction in the Intertropical Convergence Zone: as clouds attenuate CALIPSO's signal, the ratio of mismatching in the reconstruction increases.

In addition, the matching rate is strongly affected by the number of observed pixels (containing aerosols) in the grid, especially at high latitudes. Figure 4 contains a box plot analysis which indicates that sample variance is high for grids lacking sufficient data points (Fig. 4). The boxes are separated by the number of pixels in the $1^{\circ} \times 1^{\circ}$ grid. Boundaries of each box represent the 25th and 75th percentiles of the sample data in the grid, the central red line marks medians, and the length of the whiskers corresponds to approximately $\pm 2.7 \sigma$ and $99.3 \%$ coverage, assuming that the data are distributed normally. At both distances, the matching rate of aerosol increases steadily, while the span of data decreases with the number of pixels in the grid. For grids with more than 20 pixels over the two CALIPSO cycles, the average matching rate of aerosol is $75.32 \%$ at $30 \mathrm{~km}$ and $68.52 \%$ at $100 \mathrm{~km}$. This could be explained by the fact that in regions where aerosols occur more frequently (thus have more pixels observed), suitable donors are easier to find. 

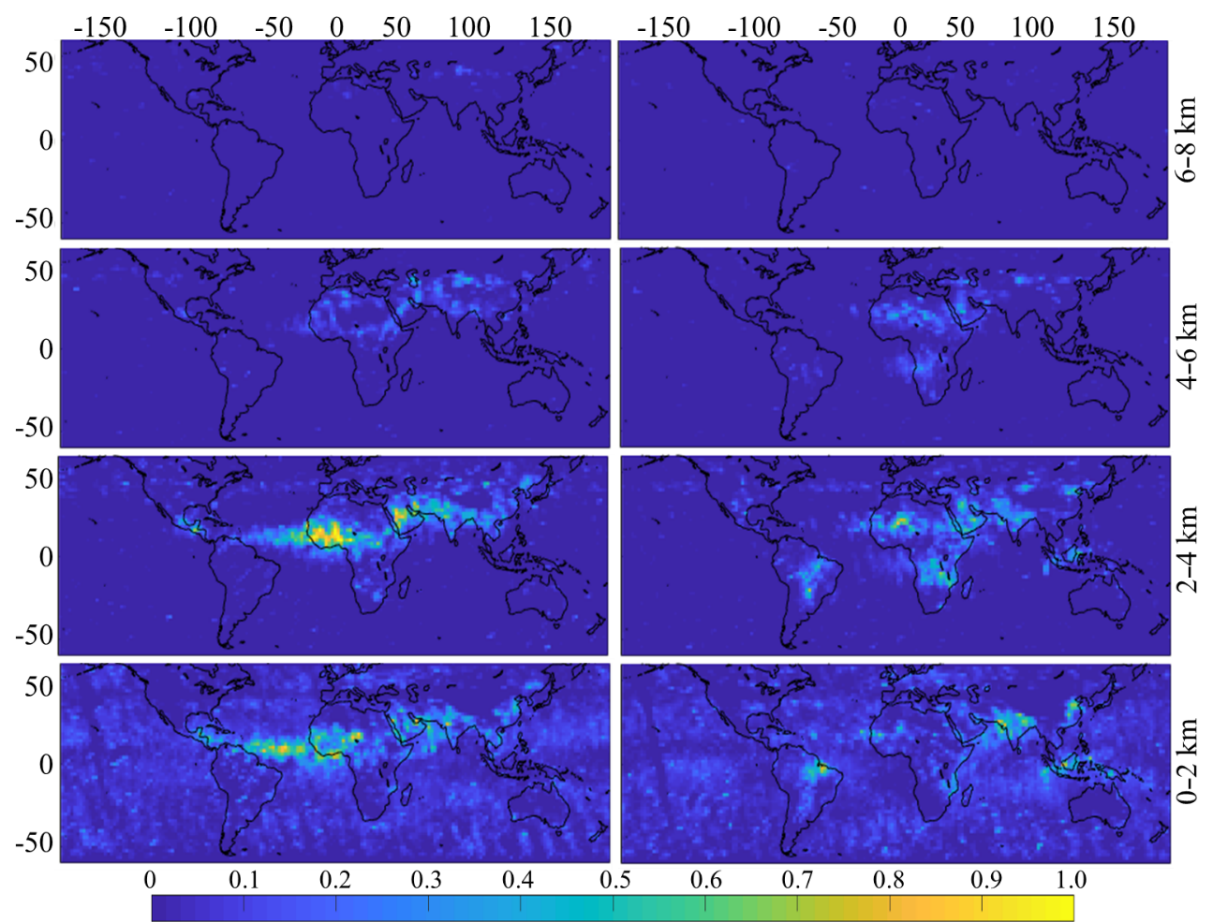

Figure 3. Height-resolved global distributions of aerosol optical depth (AOD) based on construction of RXS-expand $100 \mathrm{~km}$ on both sides of CALIPSO's ground track. Left column is for the April dataset, and the right column is for September. Data are binned on a $2^{\circ}$ latitudelongitude grid.

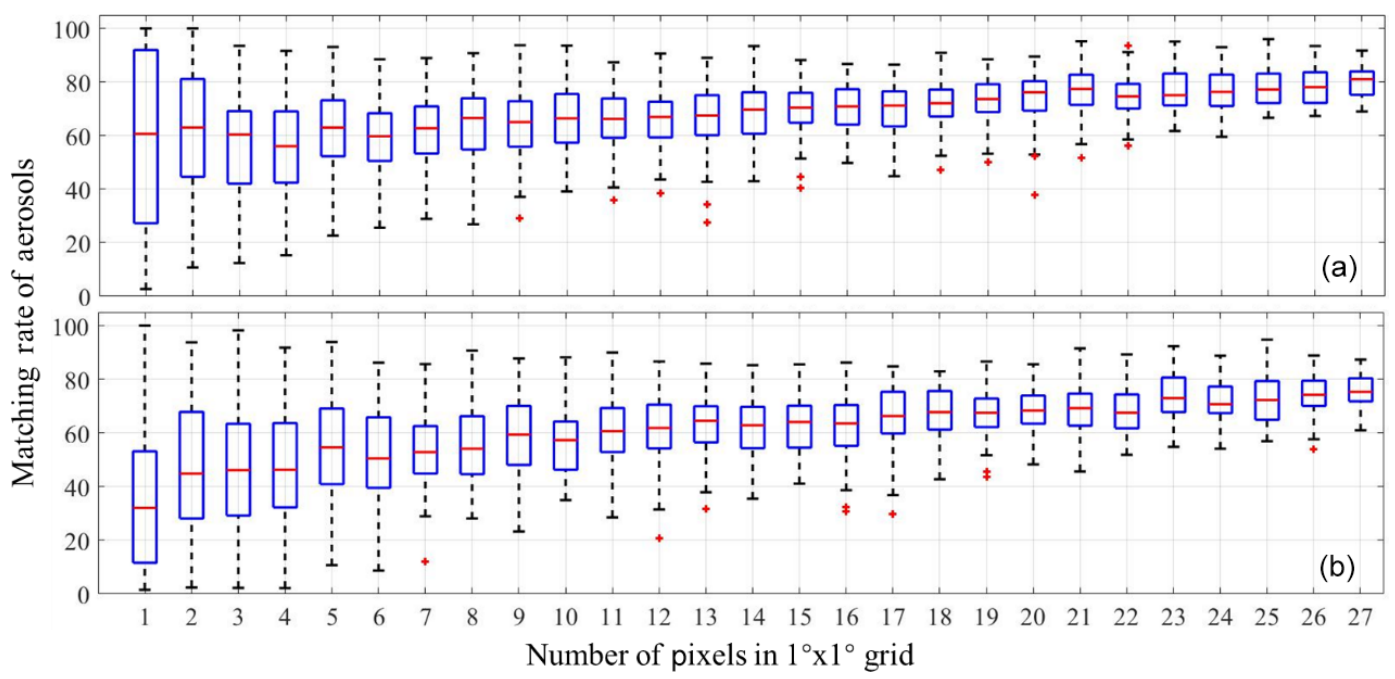

Figure 4. Matching rates of aerosols as a function of number of samples in $1^{\circ}$ grid cells for reconstructions of nadir profiles with $30 \mathrm{~km}$ dead zone (a) and $100 \mathrm{~km}$ dead zone (b). Boundaries of each box represent the 25th and 75th percentiles of the sample data in the grid, red lines indicate medians, and whiskers correspond to approximately $\pm 2.7 \sigma$ ( $99.3 \%$ coverage, assuming that data are distributed normally). Points marked with "+" are extreme outliers.

\subsection{Case study}

With the complete datasets of CALIOP profiles, and MODIS radiances and geolocation fields, construction based on the SRM method can be applied worldwide. It is applied here to aerosols along the eastern coast of Asia $\left(26-41^{\circ} \mathrm{N}, 117-\right.$ $132^{\circ} \mathrm{E}$ ) for a 3-month period (MAM) in 2015. The SRM method's AOD estimates are compared to AErosol RObotic NETwork (AERONET) values inferred from ground-based sun photometers on a day-by-day basis. 
Table 3. Summary of comparison between observed nadir profiles and reconstruct nadir profiles.

\begin{tabular}{|c|c|c|c|c|c|c|c|c|c|c|}
\hline \multicolumn{11}{|c|}{ Dead zone $-30 \mathrm{~km}$} \\
\hline & Match & Clear & Cloud & Aerosol & Mismatch & Clear & Cloud & Aerosol & No sig.* & Surf* \\
\hline \multicolumn{11}{|c|}{ 10-24 April 2015} \\
\hline \multirow[t]{2}{*}{ Actual } & 522200 & 480846 & 24057 & 17297 & 45160 & 14920 & 11665 & 6688 & 11197 & 689 \\
\hline & $100 \%$ & $92.08 \%$ & $4.61 \%$ & $3.31 \%$ & $100 \%$ & $33.04 \%$ & $25.83 \%$ & $14.81 \%$ & $24.79 \%$ & $1.53 \%$ \\
\hline \multirow[t]{2}{*}{ Theo. } & 549580 & 496553 & 31243 & 21784 & 17780 & 9298 & 4804 & 2291 & 1086 & 301 \\
\hline & $100 \%$ & $90.35 \%$ & $5.68 \%$ & $3.96 \%$ & $100 \%$ & $52.30 \%$ & $27.02 \%$ & $12.88 \%$ & $6.11 \%$ & $1.69 \%$ \\
\hline \multicolumn{11}{|c|}{ 14-29 September 2015} \\
\hline \multirow[t]{2}{*}{ Actual } & 514340 & 478282 & 19329 & 16729 & 41380 & 13770 & 10336 & 6522 & 10018 & 733 \\
\hline & $100 \%$ & $92.99 \%$ & $3.76 \%$ & $3.25 \%$ & $100 \%$ & $33.28 \%$ & $24.98 \%$ & $15.76 \%$ & $24.21 \%$ & $1.77 \%$ \\
\hline \multirow[t]{2}{*}{ Theo. } & 540220 & 493044 & 25818 & 21357 & 15500 & 8274 & 3944 & 2082 & 885 & 316 \\
\hline & $100 \%$ & $91.27 \%$ & $4.78 \%$ & $3.95 \%$ & $100 \%$ & $53.38 \%$ & $25.44 \%$ & $13.43 \%$ & $5.71 \%$ & $2.04 \%$ \\
\hline \multicolumn{11}{|c|}{ Dead zone - $100 \mathrm{~km}$} \\
\hline & Match & Clear & Cloud & Aerosol & Mismatch & Clear & Cloud & Aerosol & No sig. & Surf \\
\hline \multicolumn{11}{|c|}{ 10-24 April 2015} \\
\hline \multirow[t]{2}{*}{ Actual } & 368330 & 342896 & 12891 & 12543 & 47540 & 16977 & 11378 & 7875 & 10374 & 937 \\
\hline & $100 \%$ & $93.09 \%$ & $3.50 \%$ & $3.41 \%$ & $100 \%$ & $35.71 \%$ & $23.93 \%$ & $16.56 \%$ & $21.82 \%$ & $1.97 \%$ \\
\hline \multirow[t]{2}{*}{ Theo. } & 390690 & 357283 & 17358 & 16049 & 25180 & 13367 & 5247 & 3981 & 2066 & 520 \\
\hline & $100 \%$ & $91.45 \%$ & $4.44 \%$ & $4.11 \%$ & $100 \%$ & $53.09 \%$ & $20.84 \%$ & $15.81 \%$ & $8.20 \%$ & $2.07 \%$ \\
\hline \multicolumn{11}{|c|}{ 14-29 September 2015} \\
\hline \multirow[t]{2}{*}{ Actual } & 382520 & 359847 & 10101 & 12572 & 44020 & 15379 & 9725 & 7793 & 10112 & 1011 \\
\hline & $100 \%$ & $94.07 \%$ & $2.64 \%$ & $3.29 \%$ & $100 \%$ & $34.94 \%$ & $22.09 \%$ & $17.70 \%$ & $22.97 \%$ & $2.30 \%$ \\
\hline \multirow[t]{2}{*}{ Theo. } & 404170 & 373653 & 14077 & 16441 & 22370 & 11711 & 4117 & 3987 & 2017 & 538 \\
\hline & $100 \%$ & $92.45 \%$ & $3.48 \%$ & $4.07 \%$ & $100 \%$ & $52.35 \%$ & $18.40 \%$ & $17.82 \%$ & $9.02 \%$ & $2.41 \%$ \\
\hline
\end{tabular}

* "No sig." stands for no signal, and "Surf" stands for surface and subsurface portions of the measured columns.

The eastern coast of Asia represents one of the most complicated aerosol regions, as it includes transported natural dust; anthropogenic dust; black carbon (BC) and organic carbon (OC) from biomass burning; and mixtures of $\mathrm{BC}, \mathrm{OC}$, and sulfates from urban pollution (Logan et al., 2013; Huang et al., 2015b). Analysis of multiple AERONET sites in eastern Asia during the 2001-2010 period showed that the area is dominated by mineral dust during spring months, likely transported from the Gobi and Taklamakan deserts (Eck et al., 2005; Huang et al., 2008; Logan et al., 2013). The dominance of these outflowing aerosols continues to be observed as far away as Japan (Ikeda et al., 2014; Uchino et al., 2017).

Figure 5 shows seasonal distributions of AOD in the area. Data are binned in a $0.25^{\circ} \times 0.25^{\circ}$ latitude-longitude grid. A couple of locations with seasonal-mean AOD more than 0.5 occur on the mainland of China, surrounding the Bohai Sea, and in the Sea of Japan. Large AOD across the Bohai Sea and near the island of Japan indicates mass transportation of aerosols during this season. A region of small AOD
$(<0.1)$ exists to the east of Shanghai, which might be caused by frequent failures of satellite retrievals at the Yangtze River Delta and the Yellow Sea due to turbidity of local water. Regional distribution based on MODIS AOD products shows certain similarity but is higher in general. Note that the extremely high values (AOD > 1) over the Yellow Sea and inside of the Bohai Bay (i.e., the same area where RXS-expand shows small AOD values) result from few measurements: 10 times less than other cells. The small sample sizes from both CALIPSO and MODIS suggest the large difference here is due to difficult to handle local surface conditions.

To better analyze the source of aerosols, the area was divided into three regions along two CALIPSO ground tracks (Fig. 5). Region A mainly includes land inside China. Region $\mathrm{B}$ includes inshore coastal waters between China and the Korean Peninsula as well as part of the East China Sea and Yellow Sea. It also includes the most populated area of South Korea. Region C includes the remaining area of the Korean 

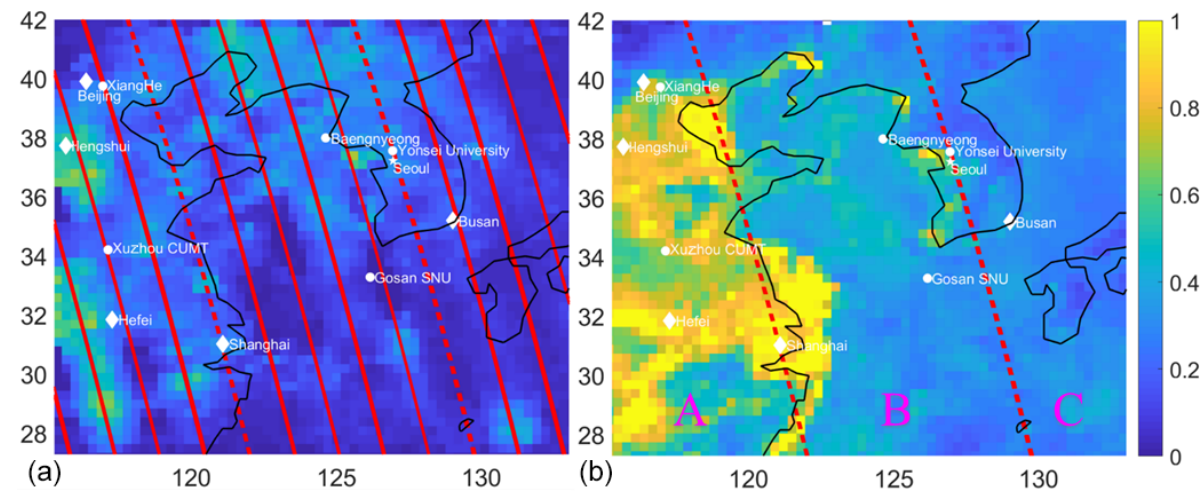

Figure 5. Seasonal distribution of aerosol optical depth (AOD) at $26-41^{\circ} \mathrm{N}, 117-132^{\circ}$ E, for March to May 2015 based on RXS-expand (a) and MODIS (b). Lines mark CALIPSO ground tracks. Dotted tracks are used as the boundaries for the analysis of aerosol subtypes in Fig. 6. White circles mark AERONET sites. Star marks the AD-Net site at Seoul. Diamonds mark some major cities.

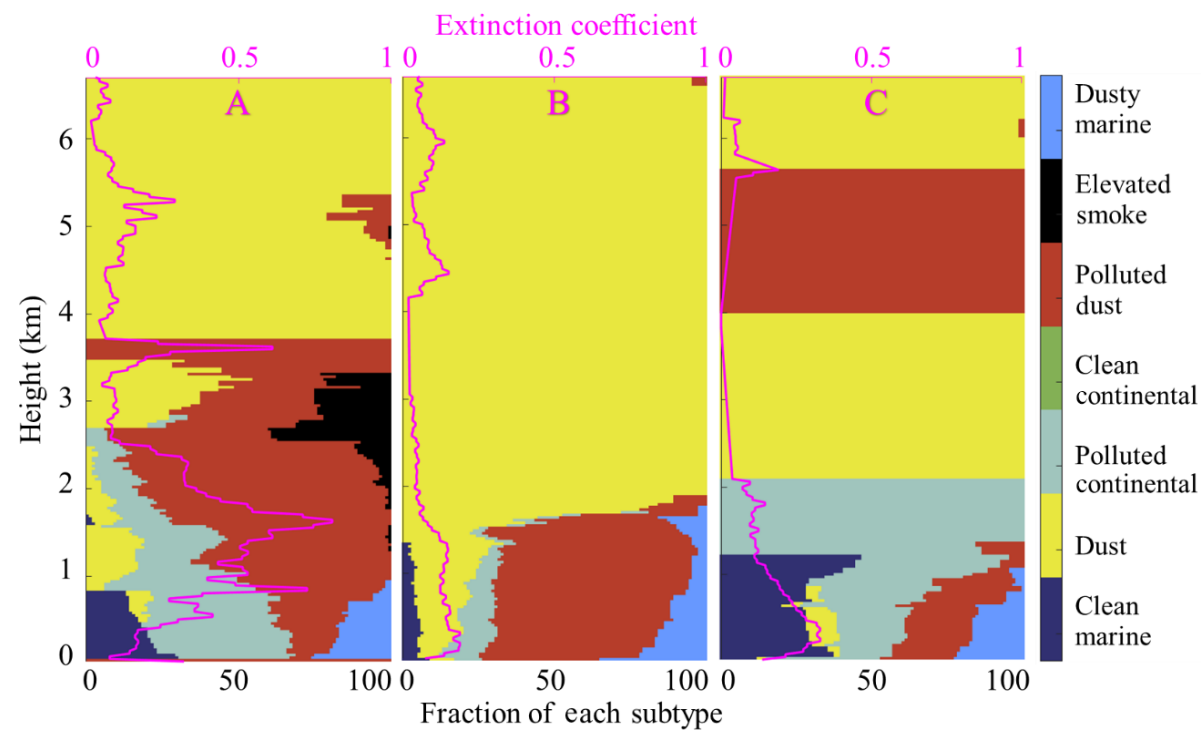

Figure 6. Vertical distributions of each aerosol subtype in region A, B, and C (see Fig. 5). Pink lines show profiles of average aerosol extinction coefficient $\left(\mathrm{km}^{-1}\right)$. The fraction is calculated as the occurrence of each subtype divided by the total occurrence of aerosols in each region.

Peninsula, the island of Kyushu in Japan, and surrounding waters.

Vertical distributions of aerosol subtypes for these regions are shown in Fig. 6. In Region A, the average extinction profile indicates aerosol layers between 1 and $2 \mathrm{~km}$, near $3.7 \mathrm{~km}$, and above $5 \mathrm{~km}$. The two lower layers are dominated by polluted dust, while the upper one is mainly clean dust. Occurrence of polluted continental aerosols and polluted dust suggests local aerosol production. The increase in smoke near $2.8 \mathrm{~km}$ suggests some transportation of biomassburning aerosols, possibly due to spring agricultural practices and indoor heating. The average extinction profile for Region B is smaller than that for Region A. These aerosols are dominated by polluted dust below $2 \mathrm{~km}$ and clean dust above. The distribution of polluted dust and dust could be ex- plained as being transported from Region A with a decrease in altitude. There might be some transport of polluted continental aerosols or dusty marine aerosols, but no transport of smoke is observed. In Region $\mathrm{C}$, the average extinction profile shows few aerosols above $2 \mathrm{~km}$ except a thin layer at $5.5 \mathrm{~km}$. The near-surface layer is composed of dust, dusty marine, clean marine, and polluted continental aerosols. The fraction of clean marine aerosols is highest among the three regions, possibly due to large ocean area and major harbors in Busan and Kyushu. The upper layer of dust and polluted dust is questionable at first glance. Detailed analysis showed that the regional AOD, with especially large values near Japan, is caused by high values on 17 April 2015. Two days before, in the afternoon of 15 April 2015, China recorded the most severe dust storm since 2002 across Beijing, known as the 

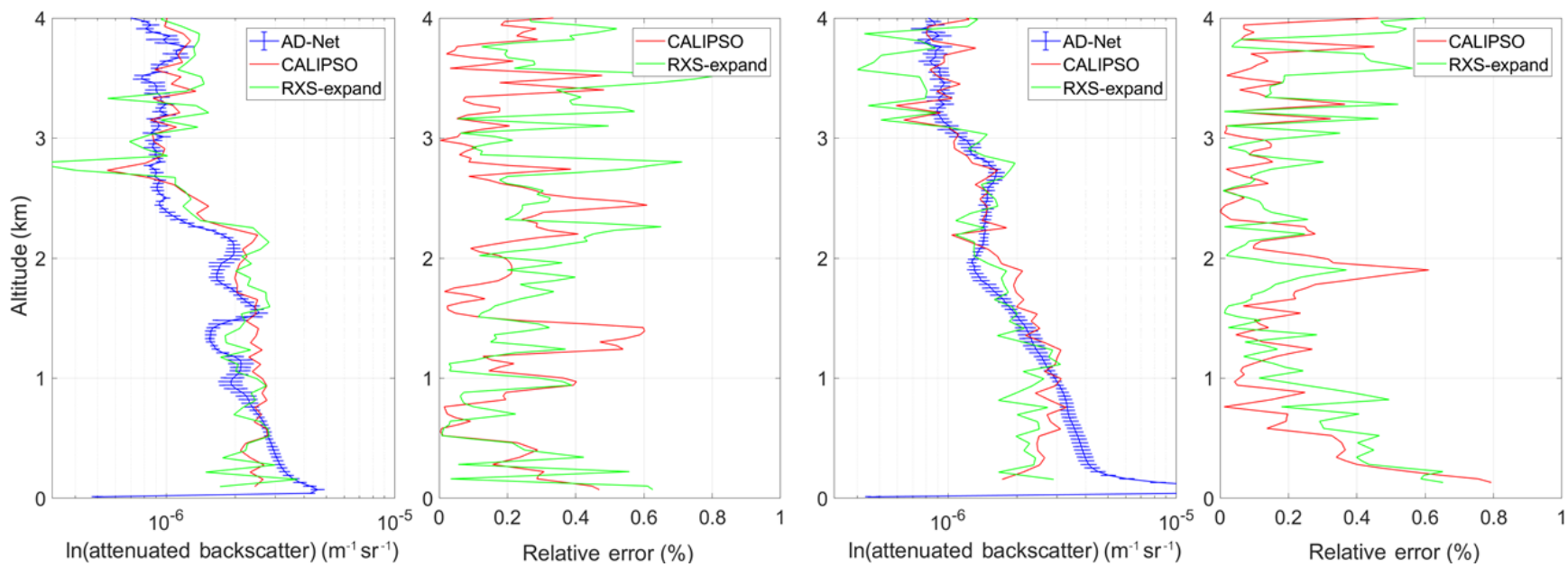

Figure 7. Comparisons among ground-based lidar profiles of $532 \mathrm{~nm}$ attenuated backscatter coefficient products (units: $\mathrm{m}^{-1} \mathrm{sr}^{-1}$; averaged $2 \mathrm{~h}$ within satellite overpass) and CALIPSO profiles at shortest distance and RXS-expand profiles that averaged $25 \mathrm{~km}$ around the location of Seoul station. The two plots on the left are from 7 March 2015, and the two plots on the right are from 24 April 2015.

"4.15 Dust Storm". Large values of AOD near Japan might be due to the influence of this major aerosol transport event, while the middle layer might be missed due to limited viewing by CALIPSO. In fact, a small region of relatively high AOD near Japan is also shown in Fig. 5 for MODIS.

In the 3-month period, the AD-Net site at Seoul, South Korea $\left(37.5^{\circ} \mathrm{N}, 127.0^{\circ} \mathrm{E}\right)$, provided measurements of atmospheric profiles that we were able to compare with those constructed in the surrounding area using the SRM method. The Seoul station has a standard lidar system in AD-Net, which is a two-wavelength (1064 and $532 \mathrm{~nm}$ ) polarizationsensitive $(532 \mathrm{~nm})$ Mie-scattering lidar, and a $532 \mathrm{~nm}$ Raman lidar (Shimizu et al., 2004). Based on the ground track, the ATrain sensors made an overpass near the station for a total of $6 \mathrm{~d}$ during that spring. However, 4 out of these $6 \mathrm{~d}$ were heavily cloudy. For the remaining $2 \mathrm{~d}, 7$ March and 24 April, the comparisons among ground-based lidar profiles, CALIPSO profiles at the shortest distance, and RXS-expand profiles at an average distance of $25 \mathrm{~km}$ around the location of Seoul station are shown Fig. 7.

The CALIPSO measurements used for comparisons are level 1.5 data products of attenuated backscatter profiles in which cloud, overcast, surface, subsurface, and totally attenuated samples have been removed before being averaged to a $20 \mathrm{~km}$ horizontal resolution. In this case, RXS-expand profiles are based on the same products. The ground-based measurements used for comparison are the $532 \mathrm{~nm}$ attenuated aerosol backscatter coefficient products, averaged within $2 \mathrm{~h}$ before and after the satellite overpass with a $15 \mathrm{~min}$ time resolution.

For the aerosol layer $0-4 \mathrm{~km}$ above the ground, the relative error between CALIPSO profiles and ground station profiles is on average $21.6 \%$ on 7 March and $18.7 \%$ on 24 April. The distances between the station and ground track are $51.0 \mathrm{~km}$ on the first day and $50.1 \mathrm{~km}$ on the second. Between RXS-expand profiles and ground station profiles, the average relative errors are $27.9 \%$ and $23.4 \%$, respectively. The results from the comparisons agreed in general. Previous studies found that there was considerable disagreement between CALIPSO measurements and ground-based lidar measurements; in most studies, the differences were found to be around 20\% (Mamouri et al., 2009; Wu et al., 2011; Kim et al., 2008; Chiang et al., 2011).

In the same period, five AERONET sites in the selected region recorded 20 comparable measurements between RXSexpand and AERONET, with the CALIPSO ground track passing within $100 \mathrm{~km}$ of AERONET sites (see Fig. 8). AERONET AOD at $500 \mathrm{~nm}$ was constrained to $\pm 2 \mathrm{~h}$ of CALIPSO's passing. The RXS-expand AOD at $532 \mathrm{~nm}$ is averaged using the 10 pixels closest to each AERONET site. Comparisons were made between RXS-expand AOD and AERONET AOD and RXS-nadir AOD and AERONET AOD. Among these collocated measurements, 17 measurements $(85 \%)$ show better agreements between AERONET and RXS-expand values of AOD. One outlier (grey circle) was found for Baengnyeong Island on 21 May. Measurements from Baengnyeong Island have a larger span than the other sites in general, which might be explained by strong sea winds across the Bohai Sea which often change direction and speed and may lead to large variations in aerosol transport. Removing the outlier, the correlation between RXS-expand AOD and AERONET AOD is $R=0.88$, whereas for RXSnadir AOD and AERONET AOD, it is $R=0.80$. Still, however, both are less than $R=0.95$ between MODIS AOD and AERONET AOD. 


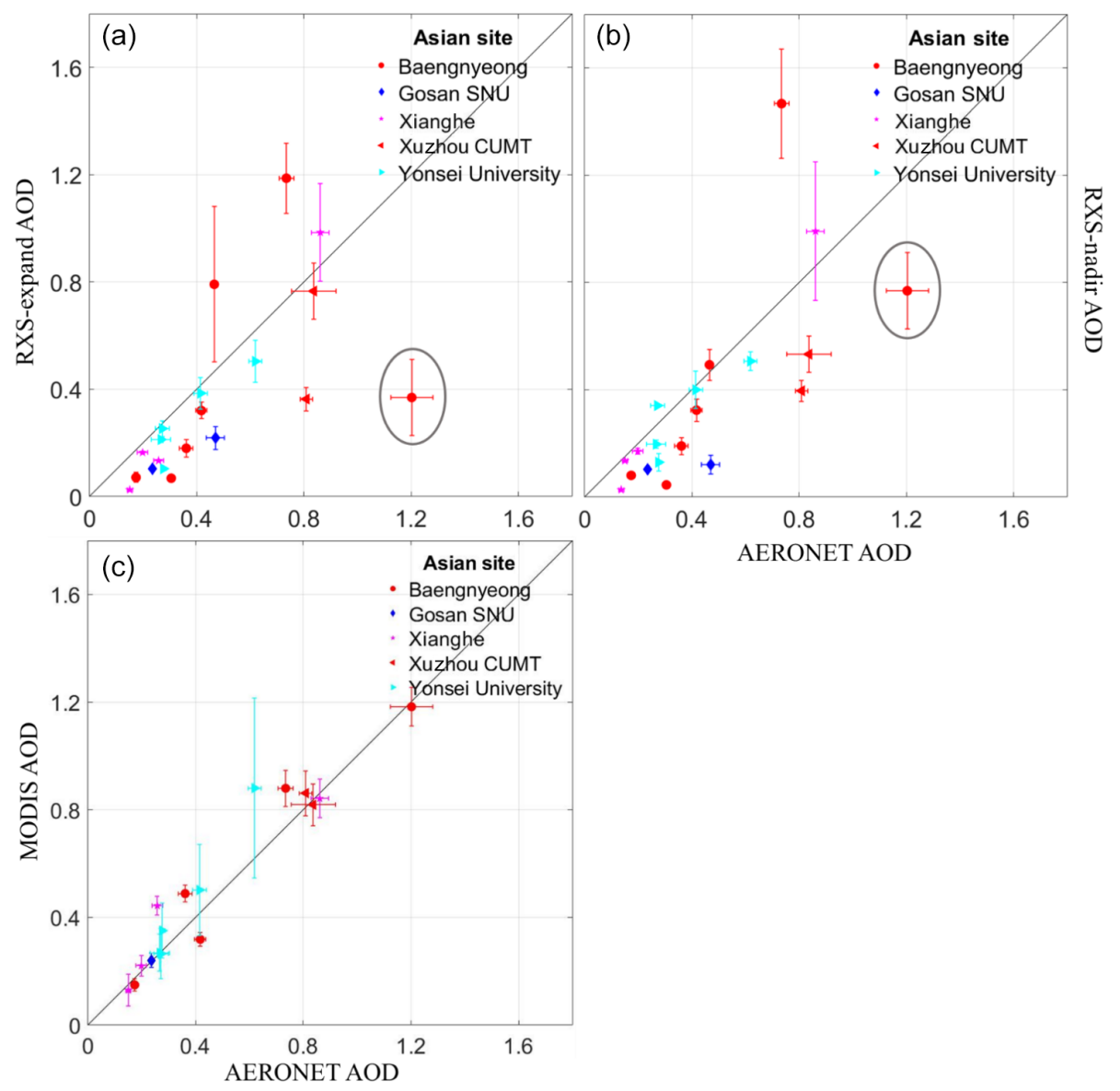

Figure 8. Comparison of collocated measurements of RXS-expand and AERONET (a), RXS-nadir and AERONET (b), and MODIS and AERONET (c). Error bars in $y$ direction indicate standard deviations of RXS-expand, RXS-nadir, or MODIS measurements within $50 \mathrm{~km}$ of the site, and bars in the $x$ direction indicate AERONET measurements within $\pm 2 \mathrm{~h}$ of CALIPSO's passing. Grey circles mark a notable outlier.

\section{Summary}

Three-dimensional aerosol structure is constructed across the globe using vertical profiles from CALIPSO and MODIS radiances. Based on matching and substituting nadir pixels (donors) into off-nadir pixels (recipients) with similar radiances, the atmosphere's vertical structure is expanded up to $100 \mathrm{~km}$ on both sides of the ground track. The construction results fill gaps between CALIPSO ground tracks and increase the frequency of observations for some areas by as much as once in $8 \mathrm{~d}$ as opposed to CALIPSO's $16 \mathrm{~d}$. Consequently, the construction algorithm approximates aerosol vertical structure at locations never measured by CALIPSO; this has the potential to improve our understanding of regional distributions of aerosols. Increasing the number of observations can also help reduce the CALIPSO-centric selection bias by allowing for the study of aerosols over short time periods and small regions.

Reconstruction of nadir profiles verifies the overall performance of using the SRM method to construct 3-D cloud- aerosol structure as a function of distance from ground track. By mimicking off-nadir distance with a dead zone along ground track profiles, reconstruction of nadir profiles shows that at $30 \mathrm{~km}$ from the RXS the SRM method correctly matches $92 \%$ of cells in April and September 2015. At $100 \mathrm{~km}$, these rates drop to $\sim 89 \%$. Comparison to TBM reconstruction suggests that the limited number of columns available from the active sensor is responsible for $\sim 3 \%$ of mismatches at $30 \mathrm{~km}$ and $\sim 6 \%$ at $100 \mathrm{~km}$. Differences between profiles reconstructed using SRM and TBM methods come mostly from profiles whose lidar signals are totally attenuated. Otherwise, the fraction of mismatching of aerosols or clouds is similar. With a sufficient number of observations, the average matching rate of aerosol could reach $75 \%$ at $30 \mathrm{~km}$ and $68 \%$ at $100 \mathrm{~km}$.

The construction algorithm was applied to the eastern coast of Asia, where heavy aerosol loadings are frequent. The expansion of RXS successfully provided regional distributions of aerosols in spring 2015. Analysis of vertical distributions of each aerosol subtype showed that regional 
west-east transportation was dominated by dust and polluted dust. Comparison of atmospheric profiles against the AD-Net lidar station shows agreement with constructed profiles and CALIPSO measurements at a similar level. Comparison of column AOD against ground-based AERONET values shows better agreement with expanded RXS relative to CALIPSO observations. The correlation increases from $R=0.80$ to $R=0.88$.

The construction of 3-D aerosol structure based on the SRM method appears as though it could be an important tool for analyzing global and regional aerosol properties. Though the matching rate is not perfect, improvements to the algorithm seem likely. The method in this work is not intended to obtain a precise quantification of aerosol profile but to provide an estimate of the column's vertical structure. We did expect, to some extent, that the estimation could be improved through calculations with constrains such as the column AOD measured by the passive sensor at the exact location of the recipient pixel, which will need a lot more work in the future. In addition, since the lack of more suitable pixels is responsible for about half of the mismatching results, we are looking forward to launching more satellites with active and passive sensors and possibly combining data from multiple satellite systems.

Data availability. NASA Level-1 and Atmosphere Archive and Distribution System (LAADS) provided MODIS data (available at http://ladsweb.nascom.nasa.gov/, MODIS Science Team, 2014a, b, 2015a, b, last access: 30 October 2019). We used the Level 1B dataset, geolocation fields, and Level 2 atmospheric aerosol product and cloud product. The NASA Langley Research Center (LaRC) provided CALIPSO VFM data (available at https://eosweb.larc. nasa.gov/project/calipso/cal_lid_12_vfm_standard_v4_20, Winker, 2018, last access: 30 October 2019).

Author contributions. SC designed the experiments, and CC helped carry them out. HWB developed the scene construction method utilized in this work and made suggestions during the progress. CD was responsible for resources and funding acquisition. JK, SW, and $\mathrm{ZZ}$ helped with data analysis. DL supervised the project and the preparation of the paper, with contributions from all co-authors.

Competing interests. The authors declare that they have no conflict of interest.

Acknowledgements. This work was supported by the National Key Research Program of China (2016YFC0200900), National Natural Science Foundation of China (NSFC; 41775023), and Excellent Young Scientist Program of Zhejiang Provincial Natural Science Foundation of China (LR19D050001). We would also like to thank all the reviewers and editor for the time spent evaluating our work and for the useful and constructive comments they gave.
Financial support. This research has been supported by the National Key Research Program of China (grant no. 2016YFC0200900), the National Natural Science Foundation of China (grant no. 41775023), and the Excellent Young Scientist Program of the Zhejiang Provincial Natural Science Foundation of China (grant no. LR19D050001).

Review statement. This paper was edited by Andrew Sayer and reviewed by three anonymous referees.

\section{References}

Ackerman, S. A., Strabala, K. I., Menzel, W. P., Frey, R. A., Moeller, C. C., and Gumley, L. E.: Discriminating clear sky from clouds with MODIS, J. Geophys. Res.-Atmos., 103, 3214132157, https://doi.org/10.1029/1998jd200032, 1998.

Badarinath, K. V. S., Kharol, S. K., Kaskaoutis, D. G., Sharma, A. R., Ramaswamy, V., and Kambezidis, H. D.: Long-range transport of dust aerosols over the Arabian Sea and Indian region A case study using satellite data and groundbased measurements, Global Planet. Change, 72, 164-181, https://doi.org/10.1016/j.gloplacha.2010.02.003, 2010.

Barker, H. W., Jerg, M. P., Wehr, T., Kato, S., Donovan, D. P., and Hogan, R. J.: A 3-D cloud-construction algorithm for the EarthCARE satellite mission, Q. J. Roy. Meteor. Soc., 137, 10421058, https://doi.org/10.1002/qj.824, 2011.

Barker, H. W., Cole, J. N. S., and Shephard, M. W.: Estimation of errors associated with the EarthCARE 3-D scene construction algorithm, Q. J. Roy. Meteor. Soc., 140, 2260-2271, https://doi.org/10.1002/qj.2294, 2014.

Baum, B. A., Soulen, P. F., Strabala, K. I., King, M. D., Ackerman, S. A., Menzel, W. P., and Yang, P.: Remote sensing of cloud properties using MODIS airborne simulator imagery during SUCCESS 2. Cloud thermodynamic phase, J. Geophys. Res.-Atmos., 105, 11781-11792, https://doi.org/10.1029/1999jd901090, 2000.

Baum, B. A., Menzel, W. P., Frey, R. A., Tobin, D. C., Holz, R. E., Ackerman, S. A., Heidinger, A. K., and Yang, P.: MODIS CloudTop Property Refinements for Collection 6, J. Appl. Meteorol. Clim., 51, 1145-1163, 10.1175/jamc-d-11-0203.1, 2012.

Breon, F. M., Tanre, D., and Generoso, S.: Aerosol effect on cloud droplet size monitored from satellite, Science, 295, 834-838, https://doi.org/10.1126/science.1066434, 2002.

Chand, D., Anderson, T. L., Wood, R., Charlson, R. J., Hu, Y., Liu, Z., and Vaughan, M.: Quantifying above-cloud aerosol using spaceborne lidar for improved understanding of cloudysky direct climate forcing, J. Geophys. Res.-Atmos., 113, D13, https://doi.org/10.1029/2007jd009433, 2008.

Chen, C., Dubovik, O., Henze, D. K., Lapyonak, T., Chin, M., Ducos, F., Litvinov, P., Huang, X., and Li, L.: Retrieval of desert dust and carbonaceous aerosol emissions over Africa from POLDER/PARASOL products generated by the GRASP algorithm, Atmos. Chem. Phys., 18, 12551-12580, https://doi.org/10.5194/acp-18-12551-2018, 2018.

Chiang, C.-W., Das, S. K., Shih, Y.-F., Liao, H.-S., and Nee, J.B.: Comparison of CALIPSO and ground-based lidar profiles 
over Chung-Li, Taiwan, J. Quant. Spectrosc. Ra., 112, 197-203, https://doi.org/10.1016/j.jqsrt.2010.05.002, 2011.

Eck, T. F., Holben, B. N., Dubovik, O., Smirnov, A., Goloub, P., Chen, H. B., Chatenet, B., Gomes, L., Zhang, X. Y., Tsay, S. C., Ji, Q., Giles, D., and Slutsker, I.: Columnar aerosol optical properties at AERONET sites in central eastern Asia and aerosol transport to the tropical mid-Pacific, J. Geophys. Res.-Atmos., 110, D6, https://doi.org/10.1029/2004jd005274, 2005.

Forsythe, J. M., Vonder Haar, T. H., and Reinke, D. L.: Cloud-base height estimates using a combination of meteorological satellite imagery and surface reports, J. Appl. Meteorol., 39, 2336-2347, https://doi.org/10.1175/15200450(2000)039<2336:cbheua>2.0.co;2, 2000.

Guerrero-Rascado, J. L., Ruiz, B., and Alados-Arboledas, L.: Multispectral Lidar characterization of the vertical structure of Saharan dust aerosol over southern Spain, Atmos. Environ., 42, 26682681, https://doi.org/10.1016/j.atmosenv.2007.12.062, 2008.

Guo, J., Liu, H., Li, Z., Rosenfeld, D., Jiang, M., Xu, W., Jiang, J. H., He, J., Chen, D., Min, M., and Zhai, P.: Aerosol-induced changes in the vertical structure of precipitation: a perspective of TRMM precipitation radar, Atmos. Chem. Phys., 18, 1332913343, https://doi.org/10.5194/acp-18-13329-2018, 2018.

Huang, J., Minnis, P., Chen, B., Huang, Z., Liu, Z., Zhao, Q., Yi, Y., and Ayers, J. K.: Long-range transport and vertical structure of Asian dust from CALIPSO and surface measurements during PACDEX, J. Geophys. Res.-Atmos., 113, D23, https://doi.org/10.1029/2008jd010620, 2008

Huang, J., Guo, J., Wang, F., Liu, Z., Jeong, M.-J., Yu, H., and Zhang, Z.: CALIPSO inferred most probable heights of global dust and smoke layers, J. Geophys. Res.-Atmos., 120, 50855100, https://doi.org/10.1002/2014jd022898, 2015a.

Huang, J. P., Liu, J. J., Chen, B., and Nasiri, S. L.: Detection of anthropogenic dust using CALIPSO lidar measurements, Atmos. Chem. Phys., 15, 11653-11665, https://doi.org/10.5194/acp-1511653-2015, 2015b.

Hunt, W. H., Winker, D. M., Vaughan, M. A., Powell, K. A., Lucker, P. L., and Weimer, C.: CALIPSO Lidar Description and Performance Assessment, J. Atmos. Ocean. Tech., 26, 1214-1228, https://doi.org/10.1175/2009jtecha1223.1, 2009.

Hutchison, K., Wong, E., and Ou, S. C.: Cloud base heights retrieved during night-time conditions with MODIS data, Int. J. Remote Sens., 27, 2847-2862, https://doi.org/10.1080/01431160500296800, 2006.

Ikeda, K., Yamaji, K., Kanaya, Y., Taketani, F., Pan, X. L., Komazaki, Y., Kurokawa, J., and Ohara, T.: Sensitivity analysis of source regions to $\mathrm{PM}_{2.5}$ concentration at Fukue Island, Japan, J. Air Waste Manage., 64, 445-452, https://doi.org/10.1080/10962247.2013.845618, 2014.

IPCC: Climate Change 2013: The Physical Science Basis. Contribution of Working Group I to the Fifth Assessment Report of the Intergovernmental Panel on Climate Change, edited by: Stocker, T. F., Qin, D., Plattner, G.-K., Tignor, M., Allen, S. K., Boschung, J., Nauels, A., Xia, Y., Bex, V., and Midgley, P. M., Cambridge University Press, Cambridge, United Kingdom and New York, NY, USA, 1535 pp, https://doi.org/10.1017/CBO9781107415324, 2013

Kahn, R. A., Chen, Y., Nelson, D. L., Leung, F. Y., Li, Q. B., Diner, D. J., and Logan, J. A.: Wildfire smoke injection heights: Two perspectives from space, Geophys. Res. Lett., 35, 4, https://doi.org/10.1029/2007gl032165, 2008.

Kato, S. and Marshak, A.: Solar zenith and viewing geometrydependent errors in satellite retrieved cloud optical thickness: Marine stratocumulus case, J. Geophys. Res.-Atmos., 114, D1, https://doi.org/10.1029/2008jd010579, 2009.

Kaufman, Y. J., Tanre, D., and Boucher, O.: A satellite view of aerosols in the climate system, Nature, 419, 215-223, https://doi.org/10.1038/nature01091, 2002.

Kim, S.-W., Berthier, S., Raut, J.-C., Chazette, P., Dulac, F., and Yoon, S.-C.: Validation of aerosol and cloud layer structures from the space-borne lidar CALIOP using a ground-based lidar in Seoul, Korea, Atmos. Chem. Phys., 8, 3705-3720, https://doi.org/10.5194/acp-8-3705-2008, 2008.

Kovacs, T. A., McCormick, M. P., Trepte, C. R., Winker, D. M., Garnier, A., and Pelon, J.: Coordination of quid pro quo groundbased measurements of cloud and aerosol optical properties for validation of the CALIPSO mission, in: Proceedings of the Society of Photo-Optical Instrumentation Engineers (Spie), Conference on Lidar Remote Sensing for Industry and Environmental Monitoring V, Honolulu, HI, 2004, WOS:000227658800030, 281-289, 2005.

Levy, R. C., Mattoo, S., Munchak, L. A., Remer, L. A., Sayer, A. M., Patadia, F., and Hsu, N. C.: The Collection 6 MODIS aerosol products over land and ocean, Atmos. Meas. Tech., 6, 29893034, https://doi.org/10.5194/amt-6-2989-2013, 2013.

Liu, D., Wang, Y., Wang, Z., and Zhou, J.: The Three-Dimensional Structure of Transatlantic African Dust Transport: A New Perspective from CALIPSO LIDAR Measurements, Adv. Meteorol., 2012, 1-9, https://doi.org/10.1155/2012/850704, 2012.

Loeb, N. G., Kato, S., Loukachine, K., and Manalo-Smith, N.: Angular distribution models for top-of-atmosphere radiative flux estimation from the Clouds and the Earth's Radiant Energy System instrument on the Terra satellite, Part I: Methodology, J. Atmos. Ocean. Tech., 22, 338-351, https://doi.org/10.1175/jtech1712.1, 2005.

Loeb, N. G., Kato, S., Loukachine, K., Manalo-Smith, N., and Doelling, D. R.: Angular distribution models for top-ofatmosphere radiative flux estimation from the Clouds and the Earth's Radiant Energy System instrument on the Terra satellite, Part II: Validation, J. Atmos. Ocean. Tech., 24, 564-584, https://doi.org/10.1175/jtech1983.1, 2007.

Logan, T., Xi, B., Dong, X., Li, Z., and Cribb, M.: Classification and investigation of Asian aerosol absorptive properties, Atmos. Chem. Phys., 13, 2253-2265, https://doi.org/10.5194/acp13-2253-2013, 2013.

Mamouri, R. E., Amiridis, V., Papayannis, A., Giannakaki, E., Tsaknakis, G., and Balis, D. S.: Validation of CALIPSO spaceborne-derived attenuated backscatter coefficient profiles using a ground-based lidar in Athens, Greece, Atmos. Meas. Tech., 2, 513-522, https://doi.org/10.5194/amt-2-513-2009, 2009.

Martins, V. S., Novo, E. M. L. M., Lyapustin, A., Aragao, L. E. O. C., Freitas, S. R., and Barbosa, C. C. F.: Seasonal and interannual assessment of cloud cover and atmospheric constituents across the Amazon (2000-2015): Insights for remote sensing and climate analysis, Int. Soc. Photogramme, 145, 309-327, https://doi.org/10.1016/j.isprsjprs.2018.05.013, 2018.

Miller, S. D., Forsythe, J. M., Partain, P. T., Haynes, J. M., Bankert, R. L., Sengupta, M., Mitrescu, C., Hawkins, J. D., and Vonder 
Haar, T. H.: Estimating Three-Dimensional Cloud Structure via Statistically Blended Satellite Observations, J. Appl. Meteorol., 53, 437-455, https://doi.org/10.1175/jamc-d-13-070.1, 2014.

Minnis, P., Trepte, Q., Sun-Mack, S., Chen, Y., Doelling, D., Young, D., Spangenberg, D., Miller, W., Wielicki, B., Brown, R., Gibson, S., and Geier, E.: Cloud detection in nonpolar regions for CERES using TRMM VIRS and Terra and Aqua MODIS data, IEEE T. Geosci. Remote, 46, 3857-3884, doi:10.1109/tgrs.2008.2001351, 2008.

MODIS Science Team: MYD021KM MODIS/Aqua Calibrated Radiances 5-Min L1B Swath $1 \mathrm{~km}$, https://doi.org/10.5067/MODIS/MYD021KM.006, last access: 30 October 2019, 2015a.

MODIS Science Team: MYD03 MODIS/Aqua Geolocation Fields 5-Min L1A Swath $1 \mathrm{~km}$, https://doi.org/10.5067/MODIS/MYD03.006, last access: 30 October 2019, 2015 b.

$\begin{array}{cccr}\text { MODIS } & \text { Science } & \text { Team: } & \text { MYD04_3K } \\ \text { MODIS/Aqua } & \text { Aerosol } & \text { 5-Min L2 } & \text { Swath } 3 \mathrm{~km} \text {, }\end{array}$ https:/doi.10.5067/MODIS/MYD04 3K.006, last access: 30 October 2019, 2014a.

MODIS Science Team: MYD06_L2 MYD06_L2 MODIS/Aqua Clouds 5-Min L2 Swath $1 \mathrm{~km}$ and $5 \mathrm{~km}$, https://doi.org/10.5067/MODIS/MYD06_L2.006, last access: 30 October 2019, 2014b.

Moosmuller, H., Chakrabarty, R. K., and Arnott, W. P.: Aerosol light absorption and its measurement: A review, J. Quant. Spectrosc. Ra., 110, 844-878, https://doi.org/10.1016/j.jqsrt.2009.02.035, 2009.

Pappalardo, G., Wandinger, U., Mona, L., Hiebsch, A., Mattis, I., Amodeo, A., Ansmann, A., Seifert, P., Linne, H., Apituley, A., Alados Arboledas, L., Balis, D., Chaikovsky, A., D’Amico, G., De Tomasi, F., Freudenthaler, V., Giannakaki, E., Giunta, A., Grigorov, I., Iarlori, M., Madonna, F., Mamouri, R. E., Nasti, L., Papayannis, A., Pietruczuk, A., Pujadas, M., Rizi, V., Rocadenbosch, F., Russo, F., Schnell, F., Spinelli, N., Wang, X., and Wiegner, M.: EARLINET correlative measurements for CALIPSO: First intercomparison results, J. Geophys. Res.Atmos., 115, D00H19, https://doi.org/10.1029/2009jd012147, 2010.

Platnick, S., King, M. D., Ackerman, S. A., Menzel, W. P., Baum, B. A., Riedi, J. C., and Frey, R. A.: The MODIS cloud products: Algorithms and examples from Terra, IEEE T. Geosci. Remote, 41, 459-473, https://doi.org/10.1109/tgrs.2002.808301, 2003.

Platnick, S., Meyer, K. G., King, M. D., Wind, G., Amarasinghe, N., Marchant, B., Arnold, G. T., Zhang, Z., Hubanks, P. A., Holz, R. E., Yang, P., Ridgway, W. L., and Riedi, J.: The MODIS Cloud Optical and Microphysical Products: Collection 6 Updates and Examples From Terra and Aqua, IEEE T. Geosci. Remote, 55, 502-525, https://doi.org/10.1109/tgrs.2016.2610522, 2017.

Remer, L. A., Mattoo, S., Levy, R. C., and Munchak, L. A.: MODIS $3 \mathrm{~km}$ aerosol product: algorithm and global perspective, Atmos. Meas. Tech., 6, 1829-1844, https://doi.org/10.5194/amt-6-18292013, 2013.

Savtchenko, A., Kummerer, R., Smith, P., Gopalan, A., Kempler, S., and Leptoukh, G.: A-Train Data Depot: Bringing Atmospheric Measurements Together, IEEE T. Geosci. Remote, 46, 27882795, doi:10.1109/tgrs.2008.917600, 2008.
Sayer, A. M., Munchak, L. A., Hsu, N. C., Levy, R. C., Bettenhausen, C., and Jeong, M. J.: MODIS Collection 6 aerosol products: Comparison between Aqua's e-Deep Blue, Dark Target, and "merged" data sets, and usage recommendations, J. Geophys. Res.-Atmos., 119, 13965-13989, https://doi.org/10.1002/2014jd022453, 2014.

Shimizu, A., Sugimoto, N., Matsui, I., Arao, K., Uno, I., Murayama, T., Kagawa, N., Aoki, K., Uchiyama, A., and Yamazaki, A.: Continuous observations of Asian dust and other aerosols by polarization lidars in China and Japan during ACE-Asia, J. Geophys. Res.-Atmos., 109, https://doi.org/10.1029/2002jd003253, 2004.

Sun, X. J., Li, H. R., Barker, H. W., Zhang, R. W., Zhou, Y. B., and Liu, L.: Satellite-based estimation of cloud-base heights using constrained spectral radiance matching, Q. J. Roy. Meteor. Soc., 142, 224-232, https://doi.org/10.1002/qj.2647, 2016.

Textor, C., Schulz, M., Guibert, S., Kinne, S., Balkanski, Y., Bauer, S., Berntsen, T., Berglen, T., Boucher, O., Chin, M., Dentener, F., Diehl, T., Easter, R., Feichter, H., Fillmore, D., Ghan, S., Ginoux, P., Gong, S., Grini, A., Hendricks, J., Horowitz, L., Huang, P., Isaksen, I., Iversen, I., Kloster, S., Koch, D., Kirkevåg, A., Kristjansson, J. E., Krol, M., Lauer, A., Lamarque, J. F., Liu, X., Montanaro, V., Myhre, G., Penner, J., Pitari, G., Reddy, S., Seland, Ø., Stier, P., Takemura, T., and Tie, X.: Analysis and quantification of the diversities of aerosol life cycles within AeroCom, Atmos. Chem. Phys., 6, 1777-1813, https://doi.org/10.5194/acp-6-17772006, 2006.

Uchino, O., Sakai, T., Izumi, T., Nagai, T., Morino, I., Yamazaki, A., Deushi, M., Yumimoto, K., Maki, T., Tanaka, T. Y., Akaho, T., Okumura, H., Arai, K., Nakatsuru, T., Matsunaga, T., and Yokota, T.: Lidar detection of high concentrations of ozone and aerosol transported from northeastern Asia over Saga, Japan, Atmos. Chem. Phys., 17, 1865-1879, https://doi.org/10.5194/acp17-1865-2017, 2017.

Vaughan, M. A., Powell, K. A., Kuehn, R. E., Young, S. A., Winker, D. M., Hostetler, C. A., Hunt, W. H., Liu, Z., McGill, M. J., and Getzewich, B. J.: Fully Automated Detection of Cloud and Aerosol Layers in the CALIPSO Lidar Measurements, J. Atmos. Ocean. Tech., 26, 2034-2050, https://doi.org/10.1175/2009jtecha1228.1, 2009.

Welton, E. J., Voss, K. J., Gordon, H. R., Maring, H., Smirnov, A., Holben, B., Schmid, B., Livingston, J. M., Russell, P. B., Durkee, P. A., Formenti, P., and Andreae, M. O.: Groundbased lidar measurements of aerosols during ACE-2: instrument description, results, and comparisons with other groundbased and airborne measurements, Tellus B, 52, 636-651, https://doi.org/10.1034/j.1600-0889.2000.00025.x, 2000.

Welton, E. J., Voss, K. J., Quinn, P. K., Flatau, P. J., Markowicz, K., Campbell, J. R., Spinhirne, J. D., Gordon, H. R., and Johnson, J. E.: Measurements of aerosol vertical profiles and optical properties during INDOEX 1999 using micropulse lidars, J. Geophys. Res.-Atmos., 107, D19, https://doi.org/10.1029/2000jd000038, 2002.

Winker, D. M., Pelon, J., and McCormick, M. P.: The CALIPSO mission: Spaceborne lidar for observation of aerosols and clouds, in: Proceedings of the Society of Photo-Optical Instrumentation Engineers (Spie), Conference on Lidar Remote Sensing for Industry and Environment Monitoring III, Hangzhou, Peoples R China, 2002, WOS:000182448300001, 1-11, 2003. 
Winker, D. M., Vaughan, M. A., Omar, A., Hu, Y. X., Powell, K. A., Liu, Z. Y., Hunt, W. H., and Young, S. A.: Overview of the CALIPSO Mission and CALIOP Data Processing Algorithms, J. Atmos. Ocean. Tech., 26, 2310-2323, https://doi.org/10.1175/2009jtecha1281.1, 2009.

Winker, D. M., Pelon, J., Coakley, J. A., Jr., Ackerman, S. A., Charlson, R. J., Colarco, P. R., Flamant, P., Fu, Q., Hoff, R. M., Kittaka, C., Kubar, T. L., Le Treut, H., McCormick, M. P., Megie, G., Poole, L., Powell, K., Trepte, C., Vaughan, M. A., and Wielicki, B. A.: THE CALIPSO MISSION A Global 3-D View of Aerosols and Clouds, B. Am. Meteorol. Soc., 91, 1211-1229, https://doi.org/10.1175/2010bams3009.1, 2010.

Winker, D.: CALIPSO Lidar Level 2 Vertical Feature Mask Data V4-20, https://doi.org/10.5067/CALIOP/CALIPSO/LID_L2_VFM-

STANDARD-V4-20, last access: 30 October 2019, 2018.
Wu, D., Wang, Z., Wang, B., Zhou, J., and Wang, Y.: CALIPSO validation using ground-based lidar in Hefei $\left(31.9^{\circ} \mathrm{N}, 117.2^{\circ} \mathrm{E}\right)$, China, Appl. Phys. B, 102, 185-195, https://doi.org/10.1007/s00340-010-4243-z, 2011.

Xu, J., Jia, J., Han, F., Zhang, Z., Du, X., and Wei, P.: Trans-pacific aerosol vertical structure revealed by spaceborne lidar CALIOP, Atmos. Environ., 201, 92-100, https://doi.org/10.1016/j.atmosenv.2018.12.035, 2019.

Zhang, X., Wang, L., Wang, W., Cao, D., Wang, X., and Ye, D.: Long-term trend and spatiotemporal variations of haze over China by satellite observations from 1979 to 2013, Atmos. Environ., 119, 362-373, https://doi.org/10.1016/j.atmosenv.2015.08.053, 2015. 